\title{
EFFECT OF ACUTE OVARIECTOMY ON MATING IN THE CYCLIC RAT
}

\author{
NEENA B. SGHWARTZ AND WILLIAM L. TALLEY \\ Department of Physiology, University of Illinois College of Medicine, \\ Chicago, Illinois, U.S.A.
}

(Received 22nd Fuly 1965)

In female rats, uterine weight increases early in pro-oestrus (Astwood, 1939; Schwartz, 1964), behavioural oestrus occurs during the early evening of prooestrus (Boling, Blandau, Soderwall \& Young, 1941) and pituitary LH content drops from a maximum at pro-oestrus to a minimum on the morning of oestrus (Schwartz \& Bartosik, 1962; Schwartz, 1964), by which time ovulation and vaginal cornification have occurred. A great deal of evidence suggests that these changes are due to a cyclic increase in ovarian secretion (see Schwartz, 1964). In a recent investigation of the timing of this ovarian secretion it was demonstrated that ovariectomy at 16.00 hours on the day before pro-oestrus, but not at 10.00 hours on the morning of pro-oestrus, blocked vaginal cornification; however, it was necessary to perform the ovariectomy at 10.00 hours on the day before pro-oestrus in order to block the uterine weight change and the LH discharge (Schwartz, 1964).

The present study investigated the time at which ovariectomy would block the mating response. Virgin female rats, running 4- or 5-day cycles and kept under previously described conditions (Schwartz \& Bartosik, 1962; Schwartz, 1964), were ovariectomized or sham-ovariectomized between 10.00 and 11.00 hours on the morning of pro-oestrus, or between 16.00 and 17.00 hours the previous afternoon (the last day of di-oestrus). Each female was paired with a male after 16.00 hours on the afternoon of pro-oestrus. The following morning (oestrus) the bottom of the cage was inspected for vaginal plugs, and the vaginal smear was examined for cornified cells and sperm. All but four of the sham-operated rats were laparotomized on this day in order to check for uterine swelling; all shams were then followed at least for 8 days and inspected for implantation sites, or were permitted to go to term. The ovariectomized rats were followed for at least 7 days to make sure that vaginal cornification did not recur and then were autopsied; uterine weight was measured as an additional criterion of completeness of ovariectomy. The data are presented in Table 1.

Of the sham controls, fewer than $100 \%$ showed vaginal cornification at oestrus, in contrast to unmated sham-operated or untreated controls (Schwartz \& Bartosik, 1962; Schwartz, 1964). Since all five of the non-cornified sham controls became pregnant and/or had ovulated at oestrus, it is apparent that they were in the proper stage of the cycle. Of the two sham-operated rats in 


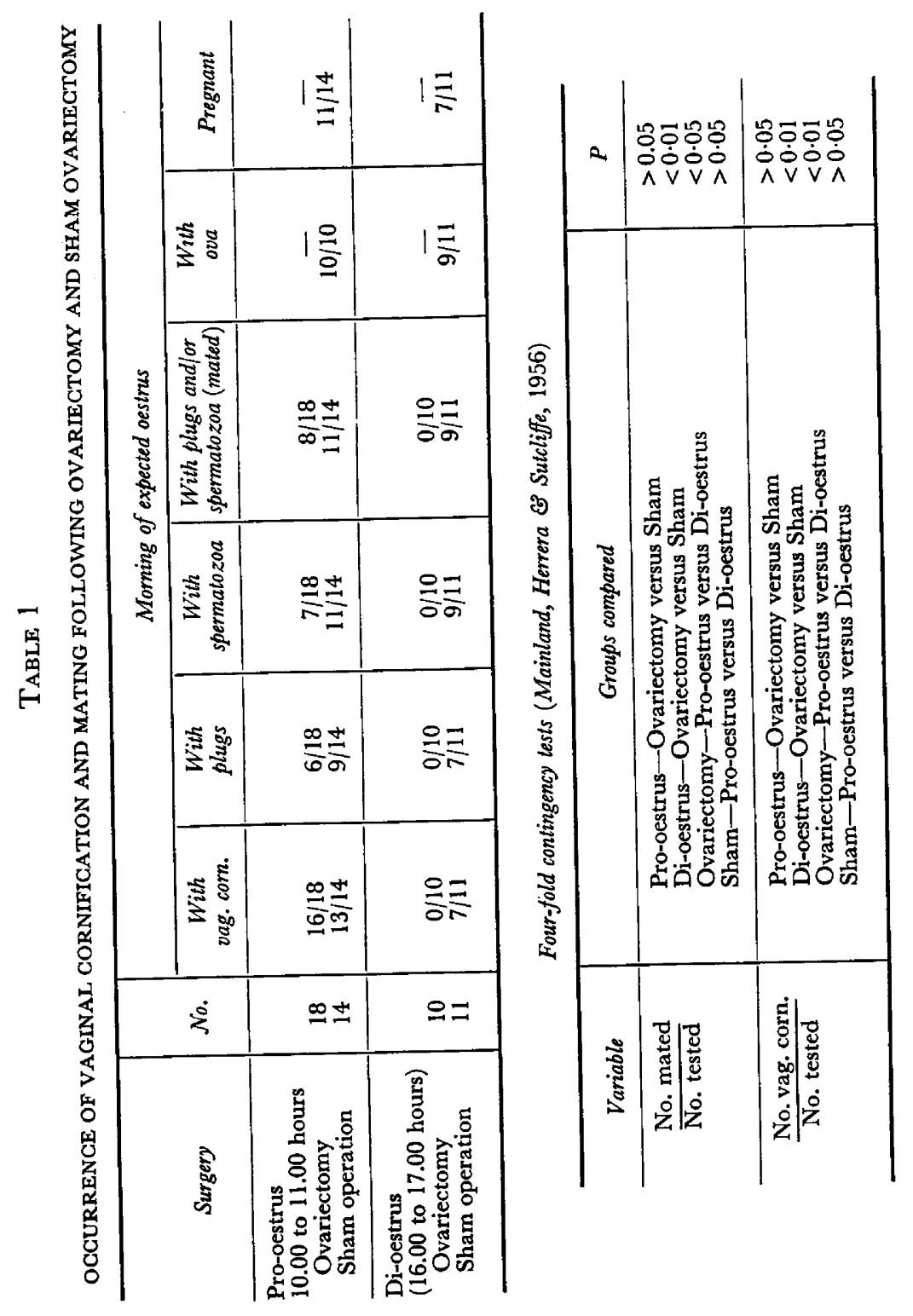


which ova were not seen at laparotomy, one had mated and became pregnant; the other had not mated. Seven of the twenty-five sham-treated rats did not become pregnant; five of these had not mated.

Vaginal cornification occurred at the normal frequency in the rats ovariectomized at pro-oestrus, but was blocked in those animals ovariectomized the previous afternoon; these data confirm the previous experiment (Schwartz, 1964). Eight rats (of the eighteen tested) mated in spite of ovary removal on the morning of pro-oestrus. The eighteen rats included five with a normal 4-day cycle, of which only one mated following ovariectomy at pro-oestrus, and thirteen with a 5-day cycle, of which seven mated. This supports the hypothesis (Schwartz, 1964) that the 5-day rat secretes ovarian steroids earlier in the cycle than the 4-day rat, with respect to the day which will be pro-oestrus. Similarly, Asch, Roos \& Aron (1964) have shown that the 5-day rat is more likely than the 4-day rat to mate on the evening before pro-oestrus. Ovariectomy on the afternoon of di-oestrus blocked mating in all rats tested (Table 1).

The results indicate that the ovary must be in situ for some time after 16.00 hours on the last day of di-oestrus in order for mating (and vaginal cornification) to occur. In the eight rats which mated in spite of ovariectomy at 10.00 hours of pro-oestrus, the ovary must already have discharged the necessary oestrogen and/or progesterone. Boling \& Blandau (1939) found that progesterone was able to elicit heat very quickly (within 3 to $11 \mathrm{hr}$ ) in ovariectomized rats primed with a small dose of oestrogen. They suggested that sexual receptivity in the normal rat is due to a synergism between the two hormones. From our data (Table 1, Schwartz, 1964), it is clear that at least enough oestrogen had been released before 10.00 hours on the day of pro-oestrus to cause cornification in virtually every rat. Astwood (1939) and Telegdy \& Endroczi (1963) have presented evidence for progesterone secretion on or before the day of prooestrus. The present experiment indicates that if progesterone secretion following oestrogen secretion is indispensable for cyclic mating behaviour, it must have occurred before 10.00 hours on the day of pro-oestrus in at least eight rats but may not yet have occurred by this time in the other ten rats.

This study was supported by Grant No. HD 00440 from the National Institute of Child Health and Human Development, Bethesda, Maryland.

We thank Dr J. P. Marbarger and Mr John Hansen who provided the environmentally controlled animal housing.

\section{REFERENCES}

Asch, G., Roos, J. \& Aron, C. (1964) Rôle joué par la folliculine dans le déclenchement de la ponte ovulaire par le coit chez la Ratte. II. Expériences chez des animaux présentant des cycles de 5 jours. C. r. Séanc. Soc. Biol. 158, 838.

Astwood, E. B. (1939) Changes in the weight and water content of the uterus of the normal adult rat. Am. F. Physiol. 126, 162.

Boling, J. L. and Blandau, R. J. (1939) The estrogen-progesterone induction of mating responses in the spayed female rat. Endocrinology, 25, 359.

Boling, J. L., Blandau, R. J., Soderwall, A. L. \& Young, W. G. (1941) Growth of the Graafian follicle and the time of ovulation in the albino rat. Anat. Rec. 79, 313.

Mainland, D., Herrera, L. \& Sutcliffe, M. (1956) Tables for use with binomial samples. N.Y. University College of Medicine, New York. 
SchwarTz, N. B. (1964) Acute effects of ovariectomy on pituitary LH, uterine weight, and vaginal cornification. Am. J. Physiol. 207, 1251.

Schwartz, N. B. \& Bartosik, D. (1962) Changes in pituitary LH content during the rat estrous cycle. Endocrinology, 71, 756.

Telegdy, G. \& Endroczi, E. (1963) The ovarian secretion of progesterone and 20a-hydroxypregn4-en-3-one in rats during the estrous cycle. Steroids, 2, 119. 